\title{
ENEMY RELEASE? AN EXPERIMENT WITH CONGENERIC PLANT PAIRS AND DIVERSE ABOVE- AND BELOWGROUND ENEMIES
}

\author{
Anurag A. Agrawal, ${ }^{1,5}$ Peter M. Kotanen, ${ }^{2}$ Charles E. Mitchell,${ }^{1,6}$ Alison G. Power, ${ }^{1}$ \\ William Godsoe, ${ }^{3,7}$ And John KliRonomos ${ }^{4}$ \\ ${ }^{1}$ Department of Ecology and Evolutionary Biology, Cornell University, Corson Hall Ithaca, New York 14853-2701 USA \\ ${ }^{2}$ Department of Botany, University of Toronto at Mississauga, 3359 Mississauga Road North, \\ Mississauga, Ontario L5L 1 C6 Canada \\ ${ }^{3}$ Department of Botany, 25 Willcocks Street, University of Toronto, Toronto, Ontario, M5S 3B2 Canada \\ ${ }^{4}$ Department of Integrative Biology, University of Guelph, 50 Stone Road East Guelph, Ontario NIG 2 Wl Canada
}

\begin{abstract}
Several hypotheses proposed to explain the success of introduced species focus on altered interspecific interactions. One of the most prominent, the Enemy Release Hypothesis, posits that invading species benefit compared to their native counterparts if they lose their herbivores and pathogens during the invasion process. We previously reported on a common garden experiment (from 2002) in which we compared levels of herbivory between 30 taxonomically paired native and introduced old-field plants. In this phylogenetically controlled comparison, herbivore damage tended to be higher on introduced than on native plants. This striking pattern, the opposite of current theory, prompted us to further investigate herbivory and several other interspecific interactions in a series of linked experiments with the same set of species. Here we show that, in these new experiments, introduced plants, on average, received less insect herbivory and were subject to half the negative soil microbial feedback compared to natives; attack by fungal and viral pathogens also tended to be reduced on introduced plants compared to natives. Although plant traits (foliar C:N, toughness, and water content) suggested that introduced species should be less resistant to generalist consumers, they were not consistently more heavily attacked. Finally, we used meta-analysis to combine data from this study with results from our previous work to show that escape generally was inconsistent among guilds of enemies: there were few instances in which escape from multiple guilds occurred for a taxonomic pair, and more cases in which the patterns of escape from different enemies canceled out. Our examination of multiple interspecific interactions demonstrates that escape from one guild of enemies does not necessarily imply escape from other guilds. Because the effects of each guild are likely to vary through space and time, the net effect of all enemies is also likely to be variable. The net effect of these interactions may create "invasion opportunity windows": times when introduced species make advances in native communities.
\end{abstract}

Key words: biotic resistance hypothesis; congeneric pairs; Darwin's naturalization hypothesis; enemy escape; herbivory; insect diversity; invasion biology; phylogenetic approaches to community ecology; plant_insect interactions; plant_virus interactions; soil microbial feedback.

\section{INTRODUCTION}

Species invasions threaten the integrity of natural ecosystems and annually cause billions of dollars of economic losses worldwide (Mack et al. 2000, Pimentel 2002). Because introduced species can cause such harm, and because the processes by which introduced species succeed address fundamental ecological theory, much recent attention has been devoted to understanding invasion biology (Mack et al. 2000, Maron and Vilà

Manuscript received 7 February 2005; revised 10 May 2005; accepted 11 May 2005. Corresponding Editor: A. R. Zangerl.

${ }^{5}$ E-mail: aa337@cornell.edu

${ }^{6}$ Present address: Department of Biology and Curriculum in Ecology, University of North Carolina, Chapel Hill, North Carolina 27599-3280 USA.

${ }^{7}$ Present address: Department of Biological Sciences, Room 252, Life Sciences Building, University of Idaho, P.O Box 443051, Moscow, Idaho 83844-3051 USA.
2001, Klironomos 2002, Bais et al. 2003, Daehler 2003, Torchin and Mitchell 2004). In particular, many recent studies have focused on the role that interspecific interactions may play in facilitating or impeding invasions (Richardson et al. 2000, Maron and Vilà 2001, Keane and Crawley 2002, Mitchell and Power 2003, Siemann and Rogers 2003, DeWalt et al. 2004, Vilà and Weiner 2004). One popular theory is the Enemy Release Hypothesis (or the Natural Enemies Hypothesis), which posits that introduced species may enjoy success in novel habitats because they lose their enemies during the invasion process (Elton 1958, Maron and Vilà 2001, Keane and Crawley 2002, Wolfe 2002, Mitchell and Power 2003, Torchin and Mitchell 2004). This loss of enemies can result in reduced levels of predation and parasitism on introduced compared to native species (Klironomos 2002, Daehler 2003), potentially allowing introduced species to outperform na- 
TABLE 1. Species employed in the experiment; all occur naturally in southern Ontario and 26 of 30 occur at our field site (Agrawal and Kotanen 2003).

\begin{tabular}{|c|c|c|c|}
\hline Plant family & Native & Introduced & $\begin{array}{l}\text { Range of } \\
\text { introduced } \\
\text { species }\end{array}$ \\
\hline (1) Asclepiadaceae & Asclepias syriaca $(\mathrm{P})$ & Cynanchum rossicum $(\mathrm{P})$ & 0.18 \\
\hline (2) Asteraceae & Lactuca canadensis $\dagger$ (B) & Lactuca serriola $\dagger$ (BA) & 1.0 \\
\hline (3) Asteraceae & Senecio pauperculus $\dagger(\mathrm{P})$ & Senecio vulgaris $\dagger$ (A) & 1.0 \\
\hline (4) Asteraceae & Artemisia campestris $\dagger$ (B) & Artemisia biennis $\dagger$ (B) & 0.76 \\
\hline (5) Brassicaceae & Lepidium densiflorum $\dagger$ (A) & Lepidium campestre $\dagger(\mathrm{AB})$ & 0.92 \\
\hline (6) Campanulaceae & Campanula rotundifolia $(\mathrm{P})$ & Campanula rapunculoides $(\mathrm{P})$ & 0.78 \\
\hline (7) Caryophyllaceae & Cerastium arvense $(\mathrm{P})$ & Cerastium fontanum $(\mathrm{P})$ & 1.0 \\
\hline (8) Caryophyllaceae & Silene antirrhina $\dagger$ (B) & Silene vulgaris $\dagger(\mathrm{P})$ & 0.82 \\
\hline (9) Chenopodiaceae & Chenopodium simplex (A) & Chenopodium album (A) & 1.0 \\
\hline (10) Plantaginaceae & Plantago rugellii $\dagger$ (AP) & Plantago major $\dagger$ (AP) & 1.0 \\
\hline (11) Poaceae & Bromus kalmii $(\mathrm{P})$ & Bromus inermis $(\mathrm{P})$ & 0.94 \\
\hline (12) Poaceae & Elymus trachycaulus $\dagger(\mathrm{P})$ & Elymus repens $\dagger(\mathrm{P})$ & 0.88 \\
\hline (13) Rosaceae & Geum aleppicum $(\mathrm{P})$ & Geum urbanum (P) & 0.20 \\
\hline (14) Rosaceae & Potentilla arguta $(\mathrm{P})$ & Potentilla recta $(\mathrm{P})$ & 0.92 \\
\hline (15) Rubiaceae & Galium boreale $(\mathrm{P})$ & Galium verum $(\mathrm{P})$ & 0.69 \\
\hline
\end{tabular}

Notes: Numbers in parentheses are used to indicate each taxonomic pair in the figures; letters in parentheses indicate plant life history following Newmaster et al. (1998): A, annual; B, biennial; P, perennial. Daggers ( $\dagger$ ) indicate that plants were replanted in 2003; otherwise, plants were established in 2002. The estimated geographic range of the introduced species is given as the proportion of the continental United States in which the introduced plant is currently found.

tives (Callaway and Aschehoug 2000, Daehler 2003, but see Colautti et al. [2004] for a critical view of the Enemy Release Hypothesis).

Recent surveys have confirmed that plant invaders often harbor smaller communities of pathogens and herbivores in their new ranges than in native areas (Memmott et al. 2000, Wolfe 2002, Mitchell and Power 2003). Although reduced regional diversity of enemies may translate to reduced levels of damage to individual plants, this is not always the case (Maron and Vilà 2001, Wolfe 2002, Agrawal and Kotanen 2003, Beckstead and Parker 2003, Colautti et al. 2004). Furthermore, we know very little about whether loss of enemies translates to reduced levels of damage relative to native counterparts in the same community. This comparison is critical because the proposed mechanism of the Enemy Release Hypothesis is that introduced organisms benefit relative to ecologically similar natives in the same environment.

In 2002, we conducted a common garden experiment on 30 locally occurring old-field plants in southern Ontario, Canada. We grouped these plants into 15 taxonomic pairs, each with one native and one introduced species, which allowed phylogenetically controlled analyses (Agrawal and Kotanen 2003). Although we reported no difference in the resistance of native and introduced plants, using a bioassay with a generalist caterpillar, naturally occurring herbivores imposed greater levels of overall damage on introduced plants than did their native congeners. This remarkable result, opposite to that of the prevailing theory (but see Hokkanen and Pimentel 1989), prompted us to further evaluate the outcome by (1) sampling herbivory for an additional year; (2) identifying the origin of the most abundant herbivores; (3) examining several other interspecific interactions with the 30 species, ranging from fungal and viral attack to soil microbial feedback; and (4) characterizing final biomass and plant traits relevant to growth and resistance. We see this extension of the original study as critical because it significantly expands the range of species interactions likely to influence the success of introduced plants, as well as the timescale of this study. As such, this study now represents the most complete experimental assessment of the Enemy Release Hypothesis to date.

We test for the sum of variation in attack by different guilds of enemies over time and predict that if introduced plants consistently escape most types of enemies, in contrast to natives, invasive ability may be reinforced. However, if effects of multiple enemies frequently occur in opposing directions, they may cancel out the advantage for introduced species.

\section{Materials And Methods}

The main experiment.-We collected seeds from southern Ontario populations of 30 herbaceous plant species (Table 1) occurring at or near our field site, the University of Toronto's Koffler Scientific Reserve at Jokers Hill: $44^{\circ} 03^{\prime} \mathrm{N}, 79^{\circ} 29^{\prime} \mathrm{W}$, near Newmarket, Ontario, Canada. These species were selected for study because (1) all occur at or near Jokers Hill; (2) all share open or semi-open upland habitats such as the old field that we used for our experiments; and (3) each introduced species could be paired with a closely related native, allowing for phylogenetically controlled analyses (Harvey and Pagel 1991, Felsenstein 2004). By focusing on phylogenetically paired species, our analyses allow us to compare levels of damage (and other traits) between species that consistently differ in origin, but otherwise are expected to be ecologically and biologically similar. Thus, the 30 species formed 14 congeneric pairs and 1 confamilial pair, in which one spe- 
cies from each pair was a native, and one a plant introduced from Europe, probably arriving in this region within the last 200 years.

Our test of enemy escape should be considered conservative for three reasons. First, enemies may have colonized the introduced plants in the years since introduction, although there may have originally been high levels of escape (Connor et al. 1980). Second, there is some possibility that the introduced plant species have been undergoing evolutionary change themselves since introduction, thereby reducing the ability to detect enemy escape (Maron et al. 2004, Stastny et al. 2005). Third, our design may make it difficult to detect enemy escape, which is predicted to be stronger for introduced plants that lack congeners in the introduced range (Darwin 1859, Rejmánek 1999).

We germinated plants in a greenhouse in the spring of 2002 and planted seedlings to a plowed field in a completely randomized design $(n=\sim 15$ plants for each of the 30 species; Agrawal and Kotanen 2003). Plants were spaced $1 \mathrm{~m}$ apart in 4 -L plastic pots sunk into the ground and filled with field soil. Use of pots facilitated the analyses of belowground microbial effects. The plot was not irrigated, but was intermittently weeded. This experiment was sampled in 2002 (Agrawal and Kotanen 2003), but was extended in 2003. Where monocarpic species flowered in the first year or a species did not have high overwinter survival, we replanted individual plants for both species in the pair (Table 1); the only pair missing from the second year was Chenopodium, for which we could not germinate the seeds. Only complete pairs, native and introduced, were used in any given analysis; not all species could be used in all analyses because of sampling limitations and plant phenology. Most analyses on traits were simple two-way ANOVAs, with taxonomic pair and origin as the main effects. Analyses were conducted with SYSTAT Version 9 (SYSTAT 1998). Because our experimental species were not chosen randomly, but instead were carefully selected from a limited list of candidates according to the criteria listed above, we chose to employ fixed ANOVA models. Assumptions of parametric statistics were checked.

Measuring enemy impact.-Percentage leaf damage by insect herbivores was estimated by destructively harvesting 10 random leaves from each plant in August 2003, and by scoring each leaf for percentage damage to the nearest $10 \%$. We visually divided each leaf into four quadrants and scored each section as being undamaged, or damaged $50 \%$ or $100 \%$. By summing over all quadrants and leaves, we obtained an estimate of the percentage of leaf area damaged over the entire plant. The same methods were employed in 2002 (Agrawal and Kotanen 2003). We were able to census herbivory on 13 of the species pairs, because some plants had completely senesced at the time of our herbivory survey. Plants were also exhaustively sampled for arthropods during the daytime every two weeks from the beginning of June to the end of August. One nocturnal census of herbivores also was conducted in August. All sedentary insects on the plants were counted and identified to species in the field where possible. Individuals that were not readily identifiable were collected for identification. Arthropods were only considered to be herbivores if they were observed feeding on the plant or were known herbivores, based on literature and field guides. To examine the effects of plant origin on herbivore species richness and abundance, we were able to use census data on 14 of the taxonomic pairs (28 species). The Asclepias-Cynanchum pair was removed from the analysis of herbivore abundance because the native species experienced an outbreak of an aphid (Myzocallis asclepiadis), with an estimated average of 17000 aphids per plant.

We examined soil microbial feedback in 10 of the species pairs. Soil feedback is the process by which plant species traits influence the relative proliferation of beneficial and pathogenic microbes in the plant rhizosphere, which in turn impact the subsequent growth of the plant species. We germinated seeds and grew plants in a glasshouse in 2 -L pots containing sterile soil, inoculated with $100 \mathrm{~mL}$ of microbial filtrate from soil associated with the respective species in the field (see Klironomos 2002). After one month of growth, we harvested the soil, extracted the microbes by preparing a new filtrate (as previously described), and included the microbes in the pots of a second "generation" of plants and grew them again for one month. Feedback is presented as the percentage difference in plant growth of generation 2 compared to generation 1 . We also examined fungal and bacterial biomass from the soil of all 15 species pairs. Soil was collected from the field in July 2003, taken as cores around the rhizosphere. Biomass values for bacteria and fungi were estimated after a filtration and differential fluorescent staining procedure as in (Klironomos et al. 1996).

Foliar fungal disease severity was measured as the percentage of leaf area visibly infected on 20 leaves per replicate plant in the main experiment. The method was similar to that for herbivory measures, although leaves were not destructively harvested. Foliar virus infection was assayed in approximately nine replicate plants from each species in 10 of the pairs using ELISA (enzyme-linked immunosorbent assay) (Crowther 1995). Prevalence of three viruses or virus groups (barley yellow dwarf viruses, cucumber mosaic virus, and potyviruses) was quantified for each species as the proportion of individuals infected by the virus. These viruses all are transmitted by aphids and infect hundreds of host species worldwide. Barley yellow dwarf viruses are restricted to grasses; cucumber mosaic virus and potyviruses infect plants from numerous families.

Measuring plant traits.-Plant morphological and physiological characteristics might vary systematically between native and invasive plants (Rejmánek and Richardson 1996, Goodwin et al. 1999), and this could 
TABLE 2. Pearson product-moment correlations for measures of species interactions and plant traits.

\begin{tabular}{|c|c|c|c|c|}
\hline Measure & $\begin{array}{c}\text { Max. herbivore } \\
\text { abundance } \neq\end{array}$ & $\begin{array}{l}\text { Herbivore species } \\
\text { richness } \dagger\end{array}$ & Herbivory $\ddagger$ & $\begin{array}{l}\text { Microbial } \\
\text { feedback\$ }\end{array}$ \\
\hline Herbivore species richness $†$ & $0.813 * * *$ & & & \\
\hline Herbivory $\ddagger$ & $0.803^{* * *} *$ & $0.557 * *$ & & \\
\hline Microbial feedback§ & 0.237 & 0.121 & 0.040 & \\
\hline Soil fungal biomass] & 0.004 & -0.002 & 0.245 & 0.157 \\
\hline Soil bacterial biomass] & -0.181 & -0.096 & -0.041 & 0.095 \\
\hline $\mathrm{C}: \mathrm{N} \dagger$ & -0.128 & -0.230 & -0.128 & -0.419 \\
\hline Leaf toughness $\dagger$ & 0.171 & 0.113 & 0.072 & 0.092 \\
\hline Leaf water content $\ddagger$ & 0.166 & 0.223 & 0.162 & 0.451 \\
\hline Plant biomass $\dagger$ & $0.284^{*}$ & $0.465 *$ & 0.254 & -0.125 \\
\hline Trichome density $\dagger$ & -0.069 & 0.142 & -0.173 & -0.260 \\
\hline
\end{tabular}

Note: Sample sizes for each correlation are determined by the lower sample value: $\dagger n=28, \neq n=26, \S n=20$, II $n=$ 30 .

$* P<0.05$; ** $P<0.01$, *** $P<0.001$. Species were the unit of replication.

help to explain differences in enemy attack (Table 2). We measured traits related to resistance and growth of plants from the main experiment: leaf water content, toughness, $\mathrm{C}: \mathrm{N}$ ratio, trichome density, and total aboveground biomass. Measurements were taken from randomly selected leaves in mid-July. Four of the five measures were taken on 14 species pairs, while leaf water content was taken on 13 pairs. Water content was measured from the fresh and dry mass of leaf discs (28 $\mathrm{mm}^{2}$ ), with eight replicates for each of the 26 species. Leaf discs were taken in the field and placed in $2-\mathrm{mL}$ tubes on ice, weighed wet, then dried at $60^{\circ} \mathrm{C}$ and weighed again. Leaf toughness was measured with a force-gauge penetrometer in the field (the average of two probes per replicate, six replicates for each of the 28 species). The $\mathrm{C}: \mathrm{N}$ ratio was calculated from new, fully expanded, leaves taken from each plant in the field. We then used five mg of dried ground leaf material in an elemental combustion system (six replicates for each of the 28 species). Trichome density was assessed by counting the tops and bottoms of leaf discs $\left(28 \mathrm{~mm}^{2}\right)$ under a microscope (five replicates for each of the 28 species).

Because some models have suggested that introduced plants will have greater biomass than their native counterparts (Daehler 2001), we measured biomass for all surviving plants in August 2003 as the dry mass of all aboveground parts.

Herbivore impact experiment.-In an additional experiment, we assessed the impacts of herbivores on the biomass of Lepidium species, a pair that showed strong evidence for enemy release in the main experiment. In particular, we tested the hypothesis that the presence of herbivory would limit the success of the native, but not the introduced, species. We planted 30 individuals of each species in the Lepidium pair to a plowed field and covered all plants with fine-mesh polyester sleeves to exclude herbivores; we then cut holes in half of the replicates for each species, allowing herbivore access. Herbivory was measured midseason on all leaves as previously described. At the end of the season, the impact of herbivores on the aboveground biomass of each species was assessed.

Meta-analysis.-Because this study reports data on enemy escape from herbivores, fungi, viruses, and soil microbes, and our previous work has reported effects on herbivory (Agrawal and Kotanen 2003) as well as seed pathogen induced mortality at two sites (Blaney and Kotanen 2001) on the same set of species, we were able to conduct a meta-analysis on our seven data sets (MetaWin 1997). We standardized data using "effect sizes" that represent an equalized currency so that values could be compared across interactions (Gurevitch et al. 2001, Lajeunesse and Forbes 2003). We used this approach, rather than MANOVA, because each of these studies used slightly different protocols, species sets, sample sizes, and statistical analyses.

\section{RESUlTS}

Interactions with foliar herbivores.-In 2003, introduced species received $22 \%$ less foliar herbivory than did their native relatives (Fig. 1; main effect of origin: $\left.F_{1,315}=4.981, P=0.026\right)$. The degree of herbivory varied among taxonomic pairs (main effect of pair: $\left.F_{12,315}=45.795, P<0.001\right)$, indicating a phylogenetic effect in enemy attack. In addition, there was a statistical interaction between species pair and origin $\left(F_{12,315}\right.$ $=4.605, P<0.001$ ), indicating variation among pairs in the strength, and in some cases the direction, of the effect of plant origin. Introduced plants exhibited less damage than did related natives in six pairs, although this was only significant for Lepidium and species of Asclepiadaceae (Appendix A, Fig. 1). Only one species pair (Cerastium) showed a significantly reversed trend (Appendix A, Fig. 1).

In contrast to theory and previous evidence (Maron and Vilà 2001, Keane and Crawley 2002, Wolfe 2002), neither the species richness of invertebrate herbivores, nor the maximum abundance of each species was consistently greater on native plants than on exotics (Fig. 1 ; Richness $F_{1,358}=0.902, P=0.342$; Maximum abundance $\left.F_{1,349}=0.269, P=0.604\right)$. Although natives did 
TABLE 2. Extended.

\begin{tabular}{|c|c|c|c|c|c|}
\hline Soil fungal biomass $\mathbb{E}$ & $\begin{array}{l}\text { Soil bacterial } \\
\text { biomass }\end{array}$ & $\mathrm{C}: \mathrm{N} \dagger$ & Leaf toughness $\dagger$ & $\begin{array}{l}\text { Leaf water } \\
\text { content } \$\end{array}$ & Plant biomass $\dagger$ \\
\hline
\end{tabular}

$\begin{array}{rr}0.545^{* *} & \\ -0.010 & 0.049 \\ 0.039 & 0.221 \\ 0.050 & 0.199 \\ -0.216 & -0.135 \\ -0.247 & -0.270\end{array}$

0.212
-0.613 ***
-0.055
0.097

-0.077
-0.196
-0.351

-0.196
-0.351
0.218

$-0.029$
$0.435^{*}$ harbor $45 \%$ more unique herbivore species (i.e., herbivores not observed on the other species in the pair) than did introduced plants, this difference was not significant (5.3 \pm 0.9 and $3.6 \pm 0.6$ unique species [mean $\pm \mathrm{SE}]$ on natives and introduced plants, respectively: $t=-1.45$, df $=26, P=0.158)$. Nearly all of the abundant herbivores were native, demonstrating that local herbivores colonized introduced plants. This latter point explains why introduced plants did not harbor a lower diversity of enemies than natives. Of the 15 most abundant herbivore species, each with at least 20 observed individuals, 13 were native. Many abundant native insect herbivores such as Dibolia borealis, Lygus lineolaris, Phyllotreta cruciferae, Phyllotreta zimmermani, and Neoneides inesticus were found feeding on both native and introduced plants, although typically only on plants within a single taxonomic pair. The earwig Forficula auricularia and the snail Trichia striolata were the only abundant herbivores of European origin. Natives and exotics did not differ in the species richness or abundance of nonherbivores (mostly insect predators and parasitoids, $P$ 's $\gg 0.05$ ).

Although there was a correlation between herbivore species richness and herbivory levels across all 26 species (Table 2), differences in herbivore richness between members of taxonomic pairs were not correlated with differences in herbivory: $n=13$ species pairs, $r$ $=0.147, P=0.632$. The latter correlation is the more critical comparison because it relates the extent of release from herbivory with the difference between paired plant species in the size of their herbivore communities.

Soil microbial feedback.-Although feedback from soil organisms almost always was negative in sign for both native and introduced plants, the reduction in growth of introduced plants was only half that in natives (Fig. 2; main effect of origin: $F_{1,138}=16.718, P$ $<0.001)$. In no case was the trend substantially reversed, indicating that interactions with underground microbes provided the most consistent evidence for enemy release among our assays (Fig. 2).

Underground microbial biomass did not differ consistently between natives and introduced plants for our bulk measures of soil bacteria and fungi. Biomass mea- sures such as these describe the entire microbial community, but do not distinguish between antagonists and mutualists. Although the main effect of origin was not significant, the effect of plant pair was highly significant for both fungal biomass $\left(F_{14,374}=8.162, P<\right.$ $0.001)$ and bacterial biomass $\left(F_{14,374}=11.171, P<\right.$ $0.001)$. In addition, we found statistical interactions between pair and origin for fungal biomass $\left(F_{14,374}=\right.$ 3.596, $P<0.001)$ and bacterial biomass $\left(F_{14,374}=\right.$ 9.296, $P<0.001$ ), simply indicating a variable effect of origin depending on the taxonomic pair.

Interactions with aboveground pathogens.-Only five congeneric pairs (10 plant species) showed visible signs of fungal pathogen attack. Fungal disease severity tended to be almost one-third higher on natives than on introduced plants, although this was not statistically significant (Fig. 3; analyses on log-transformed data: $\left.F_{1,133}=2.720, P=0.101\right)$. Note that a one-tailed interpretation of this analysis, with our a priori hypothesis of higher attack on natives, suggests a significant effect of origin. This effect was in the predicted direction for four out of five pairs, although it was reversed for Bromus (Fig. 3; interaction term $F_{4,133}=$ 3.440, $P<0.010$; Bromus: $\left.t_{26}=1.977, P=0.059\right)$. Fungal identifications are given in Appendix B.

We found evidence for virus infection in six of the 10 pairs of plants that we examined, with barley yellow dwarf virus infecting grasses (Bromus and Elymus) and cucumber mosaic virus infecting dicots (Campanula, Lactuca, Potentilla, and Silene). We found no evidence of infection by potyviruses in any of the species. On average, individuals of native species were more than twice as likely to be infected by virus than were individuals of nonnative species (12\% vs. 5.4\%), although this trend was not statistically significant. Due to low viral prevalence, we were unable to assess the interaction term; the main effect of origin, however, was not significant $(P=0.11)$. Again, a one-tailed test based on our a priori hypothesis of higher viral prevalence on natives is suggestive of an effect of origin.

Effects of plant traits and biomass.-Introduced species had, on average, significantly higher water content, lower leaf toughness, and a lower $\mathrm{C}: \mathrm{N}$ ratio than native plants (Fig. 4). Trichome density was the only trait that 

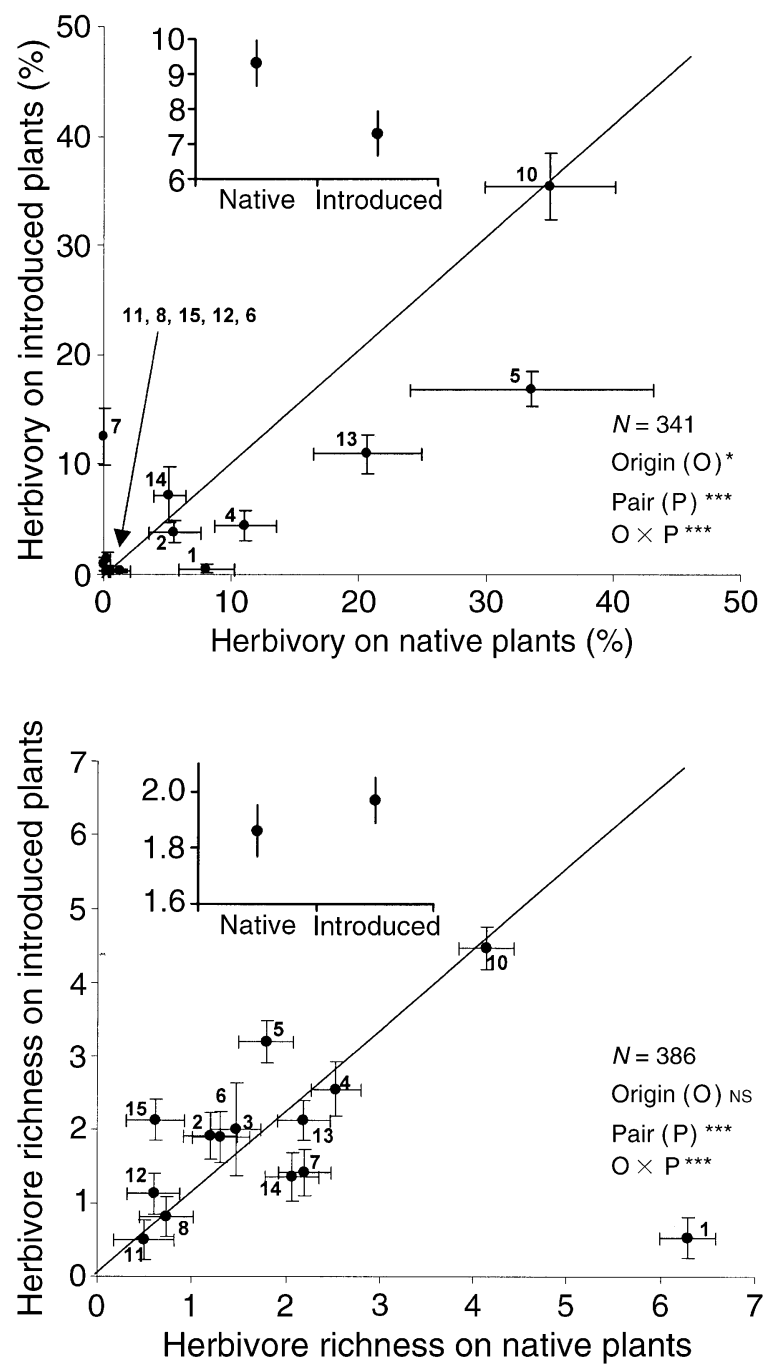

FIG. 1. Percentage foliar herbivory and species richness of herbivores on taxonomically matched pairs of native and introduced plants. The number next to each point identifies the taxonomic pair, as indicated in Table 1. Points along the line of equality indicate equal values for both members of the pair. The inset shows the overall difference between natives and introduced plants. Values are least-square means and standard errors.

$* P<0.05 ; * * P<0.01 ; * * * P<0.001 ;$ Ns indicates $P>$ 0.10 .

did not consistently vary between natives and introduced plants (Origin $F_{1,115}=0.224, P=0.637$; pair $F_{13,115}=16.527, P<0.001$; interaction between pair and origin $\left.F_{13,115}=20.187, P<0.001\right)$. We found an overall effect of natives producing more biomass than introduced plants (Fig. 4), but this effect was strongly influenced by one pair (in Asclepiadaceae), and the trend for higher biomass in natives was only found for six of the 13 pairs (Fig. 4).

Herbivore impact experiment.-Herbivory was $56 \%$ less severe for introduced $L$. campestris than for native
L. densiflorum (measured on plants exposed to herbivores, percentage leaf area damaged was $11.0 \% \pm 1.6 \%$ and $25.0 \% \pm 5.5 \%$, mean $\pm \mathrm{SE}$; separate variance $t_{15.3}$ $=-2.44, P=0.027$ ), indicating a degree of release from enemies quantitatively similar to that in the main experiment. Although the native species had greater biomass than the introduced species in the absence of herbivory, release of the introduced species from herbivory allowed it to outperform the native when exposed to herbivory (Fig. 5; interaction term between exposure to herbivory and origin: $F_{1,58}=7.470, P=$ 0.008).

Meta-analysis.-We found little overall pattern of enemy escape (Appendix A). Among taxonomic pairs, only one (Galium) showed significant escape across enemy guilds; escape from herbivores was consistent across both years for the Asclepiadaceae pair. One pair (Cerastium) showed the introduced species being more strongly impacted than the native. True to our initial individual analyses, the strongest effects across taxa were those of herbivory in 2002 and soil feedback (Appendix A).

Mean levels of enemy escape across five biotic interactions (Appendix A) did not correlate with differences in biomass between taxonomic pairs $(n=13, P$ $=0.865$ ). However, enemy escape was negatively correlated with the proportion of continental United States in which the introduced plant was found (estimated geographic range in Table 1$)(n=13, r=-0.634, P$ $=0.020)$.

\section{DISCUSSION}

Enemy release and the importance of variability.Invasions are likely to be facilitated if introduced plants suffer less from interactions with pathogens and herbivores than do native species. Our 2003 data suggest that this is sometimes the case: introduced plants suffered less leaf damage and less negative feedback from soil biota than did closely related native species. These results contrast with the data that we collected in 2002. In the previous study, we found greater levels of herbivory on introduced plants than on natives (see Agrawal and Kotanen 2003: Table 1), yet in the current analysis, natives experienced greater average levels of damage (Fig. 1). Differences in herbivory levels for the 13 species pairs were not correlated across years $(r=-0.190, P=0.533)$.

Lack of consistent differences across years may result from several factors, including: (1) changes in the herbivore fauna across years (there were some conspicuous fluctuations in the abundance of insects across years, such as the nonnative cabbage white butterfly Pieris rapae being abundant and highly damaging in 2002 , but absent from our plants in 2003); (2) ontogenetic changes in our perennial plants (this is possible given that several of our species only flowered in the 2003); and (3) a delayed response by herbivores following the establishment of the experiment. Because 
FIG. 2. Soil microbial feedback (percentage effect on plant growth) on taxonomically matched pairs of native and introduced plants. The number next to each point identifies the taxonomic pair, as indicated in Table 1. Points along the line of equality indicate equal values for both members of the pair. The inset shows the overall difference between native and introduced plants. Values are least-square means and standard errors.

$* P<0.05 ; * * P<0.01 ; * * * P<0.001$

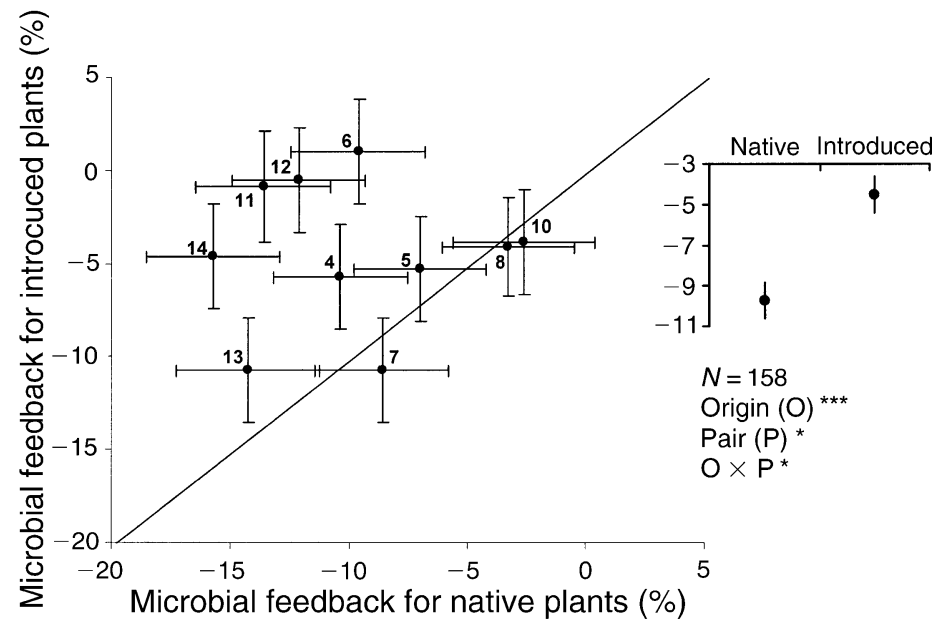

the magnitude and even direction of escape from enemies varies from year to year, examining only one year of response reveals only part of the story: such an approach may either overestimate or underestimate the overall magnitude of enemy release.

Our previous investigations of pathogen-induced seed mortality on the same set of taxonomic pairs (Blaney and Kotanen 2001) also showed variability among taxa, as well as between habitats (Appendix A). This variability is not surprising, but its existence highlights the need to examine multiple species and multiple interactions across space and time, and may help to ex-

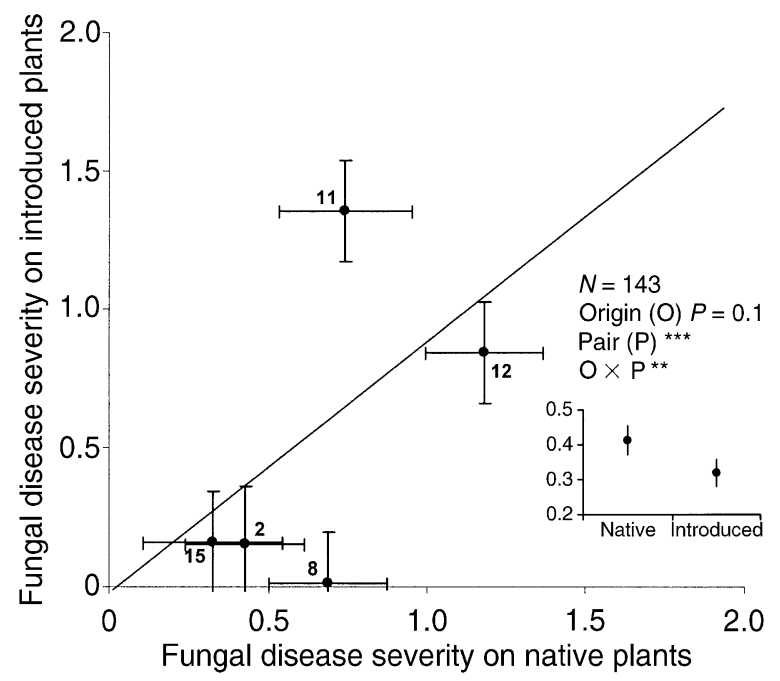

FIG. 3. Fungal disease severity (see Materials and methods: Measuring enemy impact) on taxonomically matched pairs of native and introduced plants. The number next to each point identifies the taxonomic pair, as indicated in Table 1. Points along the line of equality indicate equal values for both members of the pair. The inset shows the overall difference between natives and introduced plants. Values are least-square means and standard errors.

$* P<0.05 ; * * P<0.01 ; * * * P<0.001$. plain some of the contingent nature of the invasion process.

The spatial and temporal variability that we observed can be conceptualized following the approach of Davis et al. (2000), who theorized that fluctuating resource environments are central to our understanding of plant invasions: a plant community will be more susceptible to invasion if disturbance, grazing, or other factors sporadically lead to an increase in the resources available for invaders. In our case, this could happen if heavier attack by enemies on natives in some sites or years prevents them from monopolizing space, light, or other resources, increasing the resource supply that can be used by introduced plants. In other words, variation in levels of attack on natives, which we have clearly shown to occur, may create fluctuating conditions in which nonnative species can flourish. The average extent of enemy release may thus be relatively unimportant; instead, variation from this average determines how frequently opportunities for invasion occur. Years like 2003, when we observed the best evidence of release, may be the years in which invasions advance. Variation in enemy release also may help populations of invaders to persist by maintaining nonequilibrium conditions, preventing competitive exclusion (Davis et al. 2000).

The variation that we observed was not limited to spatial and temporal variability; we also observed striking differences among plant species and among enemy guilds. In spite of a clear tendency for introduced species to escape some of the damage suffered by natives, not all nonnatives escaped, and even those that did escape some enemies usually did not escape from both above- and belowground enemies. This result mirrors that of other studies. For example, Mitchell and Power (2003) found that introduced plants were less likely to escape from viruses than fungi, and escape from fungal pathogens was less for plant species that were heavily used by humans than for other plant species. Responses 

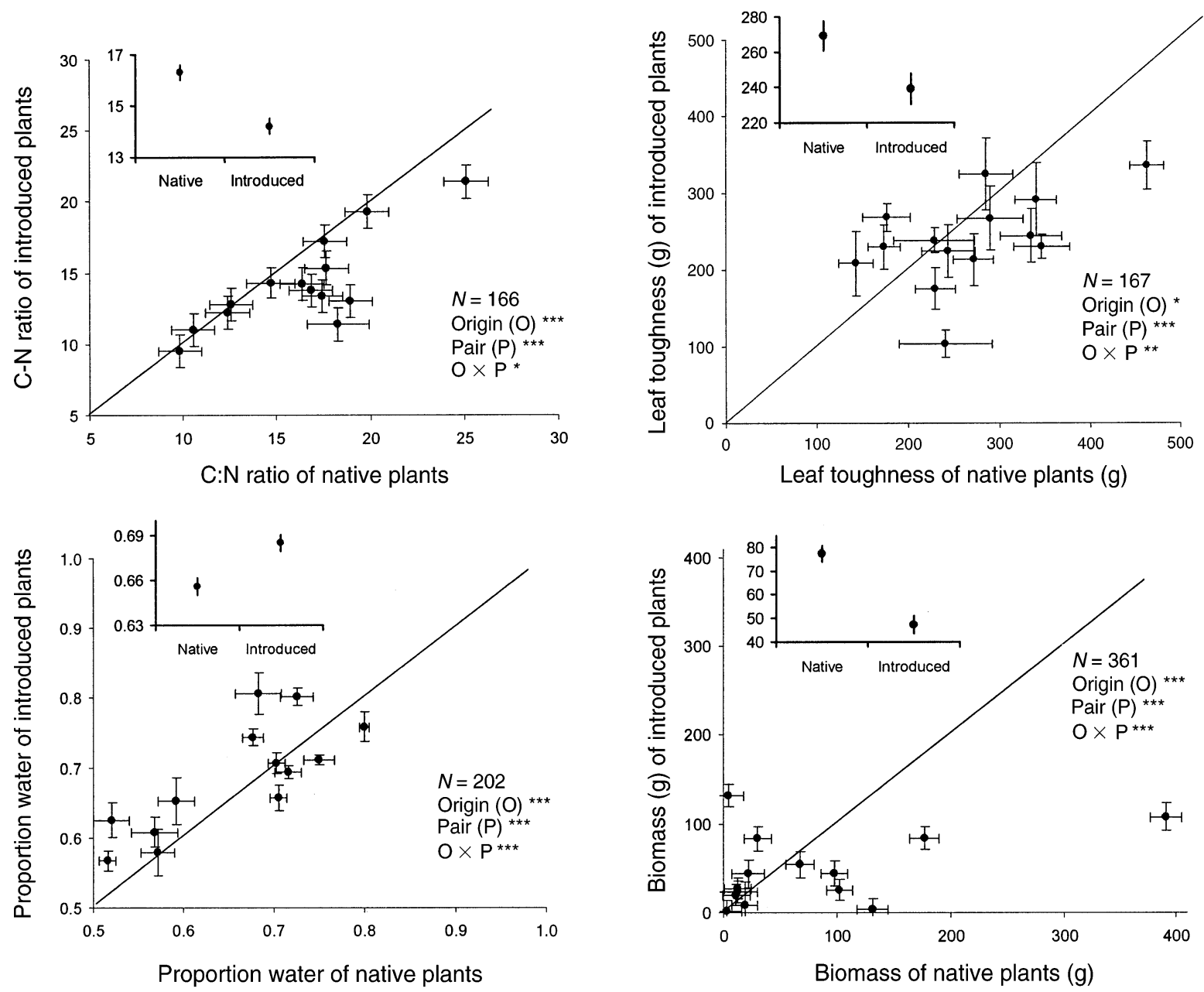

FIG. 4. Traits (C:N ratio, leaf toughness, leaf water content, and final aboveground dry biomass) of taxonomically matched pairs of native and introduced plants. The number next to each point identifies the taxonomic pair, as indicated in Table 1. Points along the line of equality indicate equal values for both members of the pair. The inset shows the overall difference between natives and introduced plants. Values are least-square means and standard errors.

$* P<0.05 ; * * P<0.01 ; * * * P 0.001$.

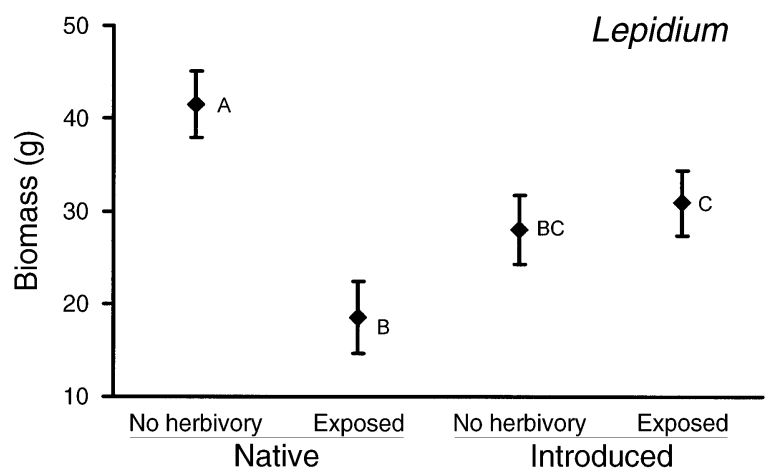

FIG. 5. Final aboveground dry biomass of Lepidium densiflorum (native) and L. campestris (introduced) with and without protection from herbivory. Values are least-square means and standard errors. Treatments sharing the same letter are not significantly different $(P>0.05)$. to different enemies need not be correlated; it is their combined impacts that will influence the success of introduced species. If aboveground and subterranean enemies both affect introduced plants less than natives, the result may be synergistic and may reinforce invasive ability; if these effects vary in opposite directions, they may cancel out. In 2003, native Artemisia and Geum experienced both greater herbivory and stronger negative soil feedback than did their introduced congeners, while the native Elymus trachycaulus showed both greater levels of foliar fungal attack and a more negative soil feedback than did the introduced Elymus repens. Nonetheless, other pairs only showed one strong interaction, or interactions in opposing directions.

One statistically significant predictor of enemy escape was the geographic range of the introduced plant: the more broadly distributed the plant, the less the ev- 
idence for enemy escape. This result suggests that geographic range sizes could be important drivers of species interactions, with more broadly distributed plants being subject to greater levels of colonization and attack (Strong et al. 1984, Torchin and Mitchell 2004). Alternatively, geographic range size may be correlated with abundance or time since introduction, indicating a buildup of enemies over space or time (Strong et al. 1984, Torchin and Mitchell 2004, Carpenter and Cappuccino 2005). Although this correlation deserves further exploration, the result strongly indicates a negative relationship between geographic spread and enemy escape.

Darwin's naturalization hypothesis.-Darwin and others have suggested that among introduced plants, those lacking native congeners should be the most likely to flourish because of the lack of very similar competitors (Darwin 1859, Rejmánek 1999, Daehler 2001). We propose that this hypothesis can be extended to the effects of phylogenetic relatedness on interspecific interactions. Because native and introduced congeners are likely to share similarities not only in resource capture, but also in chemical and physical defenses, they are likely to be attacked by common consumers (Connor et al. 1980, National Research Council 2002).

We commonly observed native herbivores attacking introduced plants within taxonomic pairs. Although it has long been known that even specialist herbivores tend to attack co-occurring species within a plant genus (Schoonhoven et al. 1998), our data extend this finding to (1) related species that have evolved on separate continents and (2) to a diverse community of aboveand belowground enemies. In a review of 18 studies, Maron and Vilà (2001) found that introduced plants often were negatively impacted by native herbivores. For example, the Eurasian watermilfoil (Myriophyllum spicatum) introduced to North America has apparently declined in some populations in response to herbivory by a native weevil (Creed and Sheldon 1995). Although the origin (native or introduced) of the microbial attackers of our plants is far less clear-cut than for herbivores, many pathogens attacked both of the plant species in a pair. The extent of enemy release thus may be amplified when the recipient flora does not contain close relatives of the invaders, because plant parasites may be much less likely to colonize and consume the introduced species. Similarly, our selection of introduced species with closely related natives, then planting them both in the same field, may have increased the potential for native enemies to colonize the introduced species. This would make our test of the predicted lesser attack on introduced species a conservative one. Notably, we found that the diversity of enemies attacking native vs. introduced species was a poor estimator of the damage actually incurred; thus, surveys of enemies should be coupled with direct estimates of their damage.
Soil mutualists and enemies.-Our most consistent evidence for different biotic interactions between native and introduced plants came from soil microbial feedback. Consistent with other recent reports (Klironomos 2002, Reinhart et al. 2003, Callaway et al. 2004, Knevel et al. 2004), we found soil microbes to impose a $4.5 \%$ reduction in biomass of introduced plants, vs. nearly a $10 \%$ decrease in biomass of natives. These effects indicate that natives are more vulnerable to negative feedback from soil pathogens and/or benefit less from positive feedback from mycorrhizae and other beneficial microbes.

Of the 10 plant species pairs assayed for soil feedback, only three are nonmycorrhizal (Lepidium, Cerastium, Silene). These three pairs all fall far to the right, along the unity line, indicating that these native species were little affected by microbial feedback, and that little difference between the native and introduced species was observed (Fig. 2). We speculate that the ability of nonmycorrhizal plants to reject mycorrhizal fungi is associated with mechanisms to prevent colonization by other fungal and bacterial invaders, and thus they show little soil feedback. The exception to this pattern was Plantago, which showed little feedback, yet is mycorrhizal and was associated with root arbuscules and vesicles in our analyses. Still, the fact that in six of our seven mycorrhizal species pairs, introduced plants suffered less negative feedback than natives, while this was not the case for our three nonmycorrhizal species, strongly suggests a link between mycorrhizal status and the ability to capture soil mutualists or escape soil pathogens.

Plant traits and biomass.-In our common garden, we found that introduced plants, on average, had a lower $\mathrm{C}: \mathrm{N}$ ratio, lower leaf toughness, and greater foliar water content than natives. An explanation for consistent differences between native and introduced plants might be that our exotics were more likely to be weedy and fast-growing species that invest less in structure and defense (Lambers and Poorter 1992, Siemann and Rogers 2003). All else being equal, these characteristics would predict greater damage by herbivores to introduced plants than to less palatable natives, and earlier feeding trials using Spodoptera exigua (Agrawal and Kotanen 2003) indeed suggested that introduced plants were not less palatable than natives. The fact that we observed greater damage on natives indicates that damage levels probably reflect a difference in the species composition of the herbivore fauna attacking the two groups, rather than a difference in food quality for a shared set of herbivores.

Some models have suggested that introduced plants will have greater biomass than their native counterparts, although evidence for this has been mixed (Daehler 2001). A formal test of the net effects of origin and enemies on plant performance requires both factors to be manipulated. Although we were only able to do this for one pair of species, we did find that herbivores 
reversed the biomass difference between native and introduced plants. This reversal in biomass production suggests that introduced L. campestris probably has the ability to outcompete native $L$. densiflorum, but only in the presence of herbivores. Ultimately, competition experiments must be conducted to fully test the effects of origin and enemies on the success and invasiveness of introduced species (Daehler 2003, Vilà and Weiner 2004).

\section{Conclusion}

Our experimental examination of 30 plant species and diverse above- and belowground enemies reveals a limited potential role for consistent enemy release in the success of introduced species, and exposes variation among enemies, taxa, space, and time. Further analyses of mutualistic interactions (Richardson et al. 2000), plant life-history traits (Table 1; see Rejmánek and Richardson 1996), invasion history (Strong et al. 1984), microevolutionary change in introduced species (Maron et al. 2004), and temporal variation (Davis et al. 2000) may help to explain some of this variation. For example, our analysis does not take into account evolutionary responses of the introduced species, which have been evolving in their new habitats for many generations.

It is clear from the present results that escape from multiple enemies in different guilds, from microbes to arthropods, is rarely positively correlated, potentially reducing the ability of introduced plants to be released from all antagonists (Appendix A). It is also clear that the magnitude and direction of escape from enemies will vary in time and space, compounding or negating the impact. Our data on variation in enemy escape are consistent with the importance of variation proposed by Davis et al. (2000). Although they argue explicitly that fluctuations in resources are powerful determinants in the susceptibility of an environment to invasion, our results suggest that the availability of enemy-free space also may have a strong and temporally variable effect on introduced species. The net effect of these interactions may create "invasion opportunity windows," times when introduced species make advances in native communities (Johnstone 1986).

\section{ACKNOWLEDGMENTS}

We thank Deborah O'Hanlon-Manners for help in the field, Deborah Tam and Jason Lye for help in the lab, James Groth for fungal identifications, Laurent Lesage for beetle identifications, Marc Lajeunesse for helping with meta-analysis, Jeffrey Nekola for identifying the snail, Pete Van Zandt for suggesting the design of the figures, and Rob Collauti, Marc Johnson, Nile Kurashige, Richard Reader, Marcel Rejmánek, Mike Stastny, Jennifer Thaler, Art Zangerl, and anonymous reviewers for comments on this manuscript. This work was supported by the Koffler Scientific Reserve at Jokers Hill, NSERC (Canada), and NSF (USA).

\section{Literature Cited}

Agrawal, A. A., and P. M. Kotanen. 2003. Herbivores and the success of exotic plants: a phylogenetically controlled experiment. Ecology Letters 6:712-715.
Bais, H. P., R. Vepachedu, S. Gilroy, R. M. Callaway, and J. M. Vivanco. 2003. Allelopathy and exotic plant invasion: from molecules and genes to species interactions. Science 301:1377-1380.

Beckstead, J., and I. M. Parker. 2003. Invasiveness of Ammophila arenaria: release from soil-borne pathogens? Ecology 84:2824-2831.

Blaney, C. S., and P. M. Kotanen. 2001. Effects of fungal pathogens on seeds of native and exotic plants: a test using congeneric pairs. Journal of Applied Ecology 38:11041113.

Callaway, R. M., and E. T. Aschehoug. 2000. Invasive plants versus their new and old neighbors: a mechanism for exotic invasion. Science 290:521-523.

Callaway, R. M., G. C. Thelen, A. Rodriguez, and W. E. Holben. 2004. Soil biota and exotic plant invasion. Nature 427:731-733.

Carpenter, D., and N. Cappuccino. 2005. Herbivory, time since introduction and the invasiveness of exotic plants. Journal of Ecology 95:315-321.

Colautti, R. I., A. Ricciardi, I. A. Grigorovich, and H. J. MacIsaaac. 2004. Is invasion success explained by the enemy release hypothesis? Ecology Letters 7:721-733.

Connor, E. F., S. H. Faeth, D. Simberloff, and P. A. Opler. 1980. Taxonomic isolation and the accumulation of herbivorous insects: a comparison of introduced and native trees. Ecological Entomology 5:205-211.

Creed, R. P., and S. P. Sheldon. 1995. Weevils and watermilfoil: did a North American herbivore cause the decline of an exotic plant? Ecological Applications 5:1113-1121.

Crowther, J. R. 1995. ELISA: theory and practice. Humana Press, Totowa, New Jersey, USA.

Daehler, C. C. 2001. Darwin's naturalization hypothesis revisited. American Naturalist 158:324-330.

Daehler, C. C. 2003. Performance comparisons of co-occurring native and alien invasive plants: implications for conservation and restoration. Annual Review of Ecology and Systematics 34:183-211.

Darwin, C. 1859. On the origin of species by means of natural selection. Murray, London, UK.

Davis, M. A., J. P. Grime, and K. Thompson. 2000. Fluctuating resources in plant communities: a general theory of invasibility. Journal of Ecology 88:528-534.

DeWalt, S. J., J. S. Denslow, and K. Ickes. 2004. Naturalenemy release facilitates habitat expansion of the invasive tropical shrub Clidemia hirta. Ecology 85:471-483.

Elton, C. S. 1958. The ecology of invasions by animals and plants. Methuen, London, UK.

Felsenstein, J. 2004. Inferring phylogenies. Sinauer Associates, Sunderland, Massachusetts, USA.

Goodwin, B. J., A. J. McAllister, and L. Fahrig. 1999. Predicting invasiveness of plant species based on biological information. Conservation Biology 13:422-426.

Gurevitch, J., P. S. Curtis, and M. H. Jones. 2001. Metaanalysis in ecology. Advances in Ecological Research 32: 199-247.

Harvey, P. H., and M. D. Pagel. 1991. The comparative method in evolutionary biology. Oxford University Press, Oxford, UK.

Hokkanen, H. M. T., and D. Pimentel. 1989. New associations in biological control: theory and practice. Canadian Entomologist 121:829-840.

Johnstone, I. M. 1986. Plant invasion windows: a time-based classification of invasion potential. Biological Reviews of the Cambridge Philosophical Society 61:369-394.

Keane, R. M., and M. J. Crawley. 2002. Exotic plant invasions and the enemy release hypothesis. Trends in Ecology and Evolution 17:164-170.

Klironomos, J. N. 2002. Feedback with soil biota contributes to plant rarity and invasiveness in communities. Nature 417:67-70. 
Klironomos, J., M. C. Rillig, and M. F. Allen. 1996. Belowground microbial and microfaunal responses to Artemisia tridentata grown under elevated atmospheric $\mathrm{CO}_{2}$. Functional Ecology 10:527-534.

Knevel, I. C., T. Lans, F. B. J. Menting, U. M. Hertling, and W. H. van der Putten. 2004. Release from native root herbivores and biotic resistance by soil pathogens in a new habitat both affect the alien Ammophila arenaria in South Africa. Oecologia 141:502-510.

Lajeunesse, M. J., and M. R. Forbes. 2003. Variable reporting and quantitative reviews: a comparison of three meta-analytical techniques. Ecology Letters 6:448-454.

Lambers, H., and H. Poorter. 1992. Inherent variation in growth rate between higher plants: a search for physiological causes and ecological consequences. Advances in Ecological Research 23:187-261.

Mack, R. N., D. Simberloff, W. M. Lonsdale, H. Evans, M. Clout, and F. A. Bazzaz. 2000. Biotic invasions: causes, epidemiology, global consequences, and control. Ecological Applications 10:689-710.

Maron, J. L., and M. Vilà. 2001. When do herbivores affect plant invasion? Evidence for the natural enemies and biotic resistance hypotheses. Oikos 95:361-373.

Maron, J. L., M. Vilà, R. Bommarco, S. Elmendorf, and P. Beardsley. 2004. Rapid evolution of an invasive plant. Ecological Monographs 74:261-280.

Memmott, J., S. V. Fowler, Q. Paynter, A. W. Sheppard, and P. Syrett. 2000. The invertebrate fauna on broom, Cytisus scoparius, in two native and two exotic habitats. Acta Oecologica 21:213-222.

MetaWin. 1997. MetaWin. Version 1.0. Sinauer Associates, Sunderland, Massachusetts, USA.

Mitchell, C. E., and A. G. Power. 2003. Release of invasive plants from fungal and viral pathogens. Nature 421:625627.

National Research Council. 2002. Predicting invasions of nonindigenous plants and pests. National Academy Press, Washington, D.C., USA.

Newmaster, S. G., A. Lehela, P. W. C. Uhlig, S. McMurray, and M. J. Oldham. 1998. Ontario plant list. Forest Research Paper Number 123. Ontario Forest Research Institute, Sault Sainte Marie, Ontario, Canada.
Pimentel, D., editor. 2002. Biological invasions: economic and environmental costs of alien plant, animal, and microbe species. CRC, Boca Raton, Florida, USA.

Reinhart, K. O., A. Packer, W. H. van der Putten, and K. Clay. 2003. Plant-soil biota interactions and spatial distribution of black cherry in its native and invasive ranges. Ecology Letters 6:1046-1050.

Rejmánek, M. 1999. Invasive plant species and invasible ecosystems. Pages 79-102 in O. D. Sandlund, P. J. Schei, and A. Viken, editors. Invasive species and biodiversity management. Kluwer Academic Publishers, Dordrecht, The Netherlands.

Rejmánek, M., and D. M. Richardson. 1996. What attributes make some plant species more invasive? Ecology 77:16551661.

Richardson, D. M., N. Allsopp, C. M. D’Antonio, S. J. Milton, and M. Rejmánek. 2000. Plant invasions: the role of mutualisms. Biological Reviews 75:65-93.

Schoonhoven, L., T. Jermy, and J. van Loon. 1998. Insectplant biology. Chapman and Hall, London, UK.

Siemann, E., and W. E. Rogers. 2003. Increased competitive ability of an invasive tree may be limited by an invasive beetle. Ecological Applications 13:1503-1507.

Stastny, M., U. Schaffner, and E. Elle. 2005. Do vigour of introduced populations and escape from specialist herbivores contribute to invasiveness? Journal of Ecology 93: 27-37.

Strong, D. R., J. H. Lawton, and R. Southwood. 1984. Insects on plants. Harvard University Press, Cambridge, Massachusetts, USA.

SYSTAT 1998. SYSTAT. Version 9. SPSS, Chicago, Illinois, USA.

Torchin, M. E., and C. E. Mitchell. 2004. Parasites, pathogens, and invasions by plants and animals. Frontiers in Ecology and the Environment 2:183-190.

Vilà, M., and J. Weiner. 2004. Are invasive plant species better competitors than native plant species? Evidence from pair-wise experiments. Oikos 105:229-238.

Wolfe, L. M. 2002. Why alien invaders succeed: support for the escape-from-enemy hypothesis. American Naturalist 160:705-711.

\section{APPENDIX A}

A table showing summary effect sizes (Hedge's $D$ and $95 \%$ confidence intervals in parentheses) for each of five species interactions on the congeneric native-introduced plant pairs is available in ESA's Electronic Data Archive: Ecological Archives E086-162-A1.

\section{APPENDIX B}

A table showing fungal disease severity (percentage of leaf surface affected) on five of the congeneric species pairs of taxonomically matched plants is available in ESA's Electronic Data Archive: Ecological Archives E086-162-A2. 


\section{Ecological Archives E086-162-A1}

Anurag A. Agrawal, Peter M. Kotanen, Charles E. Mitchell, Alison G. Power, William Godsoe, and John Klironomos. 2005. Enemy release? An experiment with congeneric plant pairs and diverse above- and belowground enemies. Ecology 86:2979-2989.

Appendix A (Table A1). Summary effect sizes (Hedge's $D$ and 95\% confidence intervals in parentheses) for each of five species interactions on the congeneric native-introduced plant pairs (Gurevitch et al. 2001, Lajeunesse and Forbes 2003).

\begin{tabular}{|c|c|c|c|c|c|c|}
\hline & $\begin{array}{l}\text { Herbivory } \\
2002\end{array}$ & $\begin{array}{c}\text { Herbivory } \\
2003\end{array}$ & $\begin{array}{l}\text { Microbial } \\
\text { feedback }\end{array}$ & $\begin{array}{l}\text { Fungal } \\
\text { disease }\end{array}$ & $\begin{array}{c}\text { Virus } \\
\text { infection }\end{array}$ & $\begin{array}{l}\text { Seed pathogen } \\
\text { (wet sites) }\end{array}$ \\
\hline Artemisia & $\begin{array}{l}-1.323 \\
(-2.385,-0.261)\end{array}$ & $\begin{array}{l}0.750 \\
(-0.083,1.583)\end{array}$ & $\begin{array}{l}0.582 \\
(-0.419,1.582)\end{array}$ & & & \\
\hline $\begin{array}{l}\text { Asclepias / } \\
\text { Cynanchum }\end{array}$ & $\begin{array}{l}0.943 \\
(0.162,1.724)\end{array}$ & $\begin{array}{l}1.265 \\
(0.467,2.063)\end{array}$ & & & & \\
\hline Bromus & $\begin{array}{l}0.054 \\
(-0.714,0.822)\end{array}$ & $\begin{array}{l}-0.073 \\
(-0.863,0.717)\end{array}$ & $\begin{array}{l}1.337 \\
(0.215,2.458)\end{array}$ & $\begin{array}{l}-0.680 \\
(-1.449,0.090)\end{array}$ & $\begin{array}{l}-0.429 \\
(-1.829,0.971)\end{array}$ & $\begin{array}{l}0.382 \\
(-0.551,1.314)\end{array}$ \\
\hline Campanula & $\begin{array}{l}-1.579 \\
(-2.566,-0.591)\end{array}$ & $\begin{array}{l}-0.675 \\
(-1.555,0.205)\end{array}$ & $\begin{array}{l}1.121 \\
(0.067,2.175)\end{array}$ & & $\begin{array}{l}1.158 \\
(0.092,2.224)\end{array}$ & $\begin{array}{l}-0.269 \\
(-1.174,0.636)\end{array}$ \\
\hline Cerastium & $\begin{array}{l}-0.433 \\
(-1.124,0.257)\end{array}$ & $\begin{array}{l}-1.877 \\
(-2.738,-1.017)\end{array}$ & $\begin{array}{l}-0.272 \\
(-1.257,0.712)\end{array}$ & & & $\begin{array}{l}-0.040 \\
(-0.941,0.860)\end{array}$ \\
\hline Chenopodium & $\begin{array}{l}-0.348 \\
(-1.310,0.615)\end{array}$ & & & & & \\
\hline Elymus & $\begin{array}{l}-0.490 \\
(-1.205,0.225)\end{array}$ & $\begin{array}{l}-0.496 \\
(-1.211,0.220)\end{array}$ & $\begin{array}{l}1.102 \\
(0.050,2.154)\end{array}$ & $\begin{array}{l}0.437 \\
(-0.275,1.150)\end{array}$ & $\begin{array}{l}0.404 \\
(-0.516,1.323)\end{array}$ & $\begin{array}{l}-0.769 \\
(-1.756,0.218)\end{array}$ \\
\hline Galium & $\begin{array}{l}1.052 \\
(0.243,1.862)\end{array}$ & $\begin{array}{l}-0.112 \\
(-0.872,0.647)\end{array}$ & & $\begin{array}{l}0.377 \\
(-0.408,1.161)\end{array}$ & & $\begin{array}{l}0.604 \\
(-0.317,1.525)\end{array}$ \\
\hline Geum & $\begin{array}{l}-0.573 \\
(-1.366,0.221)\end{array}$ & $\begin{array}{l}0.721 \\
(-0.081,1.523)\end{array}$ & $\begin{array}{l}0.435 \\
(-0.591,1.461)\end{array}$ & & & $\begin{array}{l}0.235 \\
(-0.669,1.138)\end{array}$ \\
\hline Lactuca & $\begin{array}{l}0.603 \\
(-0.163,1.369)\end{array}$ & $\begin{array}{l}0.263 \\
(-0.530,1.056)\end{array}$ & & $\begin{array}{l}0.507 \\
(-0.264,1.278)\end{array}$ & $\begin{array}{l}-0.421 \\
(-1.248,0.406)\end{array}$ & $\begin{array}{l}-0.550 \\
(-1.468,0.367)\end{array}$ \\
\hline Lepidium & $\begin{array}{l}-0.227 \\
(-0.945,0.491)\end{array}$ & $\begin{array}{l}1.078 \\
(0.126,2.029)\end{array}$ & $\begin{array}{l}0.263 \\
(-0.722,1.247)\end{array}$ & & & $\begin{array}{l}-0.037 \\
(-0.937,0.864)\end{array}$ \\
\hline Plantago & $\begin{array}{l}-0.841 \\
(-1.6,-0.081)\end{array}$ & $\begin{array}{l}-0.022 \\
(-0.763,0.719)\end{array}$ & $\begin{array}{l}-0.151 \\
(-1.167,0.865)\end{array}$ & & & $\begin{array}{l}0.805 \\
(-0.106,1.716)\end{array}$ \\
\hline
\end{tabular}




\begin{tabular}{|l|l|l|l|l|l|l}
\hline Potentilla & -0.663 & -0.346 & $\mathbf{1 . 3 7 5}$ & & 0.091 & 0.013 \\
& $(-1.930,0.604)$ & $(-1.221,0.529)$ & $\mathbf{( 0 . 2 8 5 , 2 . 4 6 5 )}$ & & $(-0.897,1.079)$ & $(-0.888,0.913)$ \\
\hline Senecio & -0.252 & & & & & \\
& $(-1.724,1.221)$ & & & & & \\
\hline Silene & -0.418 & 0.454 & -0.129 & $\mathbf{0 . 7 5 3}$ & 0.662 & -0.833 \\
& $(-1.130,0.294)$ & $(-0.304,1.211)$ & $(-1.083,0.824)$ & $(\mathbf{0 . 0 2 5 , \mathbf { 1 . 4 8 2 }})$ & $(-0.218,1.541)$ & $(-1.771,0.106)$ \\
\hline Mean & $\mathbf{- 0 . 2 2 5}$ & 0.0700 & $\mathbf{0 . 5 1 7}$ & 0.293 & 0.254 & -0.030 \\
& $(\mathbf{- 0 . 4 3 8 , - \mathbf { 0 . 0 1 1 } )}$ & $(-0.153,0.293)$ & $\mathbf{( 0 . 1 9 3 , 0 . 8 4 1 )}$ & $(-0.043,0.630)$ & $(-0.143,0.650)$ & $(-0.307,0.247)$ \\
\hline
\end{tabular}

Notes: Data for Herbivory 2002 are from Agrawal and Kotanen (2003) and data for seed pathogens is from Blaney and Kotanen (2001). Effect sizes represent an equalized currency so that values can be compared across interactions (Gurevitch et al. 2001). Positive values indicate enemy escape, while negative values indicate the introduced plants had greater enemy attack than natives. Bolded cells represent values significant significantly different from zero. Mean escape was calculated by meta-analysis (MetaWin 1.0) for each taxonomic pair (right-most column) and for each interaction across taxonomic pairs (bottom row). Metaanalysis was not appropriate for the two genera where only one interaction was assessed. Blank spaces in this table represent the lack of data.

\section{LITERATURE CITED}

Agrawal, A. A., and P. M. Kotanen. 2003. Herbivores and the success of exotic plants: a phylogenetically controlled experiment. Ecology Letters 6:712-715.

Blaney, C. S., and P. M. Kotanen. 2001. Effects of fungal pathogens on seeds of native and exotic plants: a test using congeneric pairs. Journal of Applied Ecology 38:1104-1113.

Gurevitch J., P. S. Curtis, and M. H. Jones. 2001. Meta-analysis in ecology. Advances in Ecological Research 32:199-247.

Lajeunesse, M. J., and M. R. Forbes. 2003. Variable reporting and quantitative reviews: a comparison of three meta-analytical techniques. Ecology Letters 6:448-454. 


\section{Ecological Archives E086-162-A2}

\section{Anurag A. Agrawal, Peter M. Kotanen, Charles E. Mitchell, Alison G. Power, William Godsoe, and John Klironomos. 2005. Enemy release? An experiment with congeneric plant pairs and diverse above- and belowground enemies. Ecology 86:2979-2989.}

Appendix B (Table B1). Fungal disease severity (percent of leaf surface affected) on five of the congeneric species pairs of taxonomically matched plants.

$\begin{array}{lll}\text { Plant species } & \text { Pathogen species } & \text { Mean } \pm \text { SE severity } \\ \text { Silene antirrhina* } & \text { Phyllosticta } \text { sp. } & 0.69 \pm 0.32 \\ \text { Silene vulgaris } & \text { unidentified leaf spot } & 0.013 \pm 0.012 \\ \text { Lactuca canadensis* } & \text { Septoria } \text { sp. } & 0.42 \pm 0.17 \\ \text { Lactuca serriola } & \text { unidentified leaf spot } & 0.008 \pm 0.008 \\ & \text { Bremia lactucae } & 0.14 \pm 0.63 \\ \text { Galium boreale } * & \text { unidentified purple leaf blotch } & 0.32 \pm 0.18 \\ \text { Galium verum } & \text { unidentified leaf spot } & 0.16 \pm 0.067 \\ \text { Bromus kalmii* } & \text { Puccinia coronata } & 0.12 \pm 0.041 \\ & & \\ & \text { Bipolaris sorokiniana } & 0.62 \pm 0.17\end{array}$

Bromus inermis

Puccinia coronata

$0.17 \pm 0.048$

Septoria nodorum and Ramularia sp. $1.18 \pm 0.23$

Elymus trachycaulus* Puccinia coronata

$0.19 \pm 0.079$

Septoria nodorum

$0.99 \pm 0.16$

Elymus repens

Puccinia coronata

$0.47 \pm 0.14$

Septoria nodorum and Ramularia sp. $0.037 \pm 0.092$

Notes: Starred plant species are native. Non-listed species lacked visible signs of fungal infection. 